ORIGIMLL PAPERS

報 文

(6)
固定届你媒による同位元素交換反応の

速度に対する反底気体流速の影響*

阪田貞 弘**・森田微 笔**

要 首

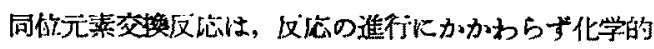
には組成の変化を生しないから、同位元素效果が無視し

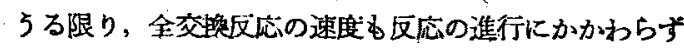
一定であり，微分反分器と同一の好果を有する。また反 応熱が注とんと零であるから，外的条俳による以外温度 の变動を考虑する必要がない。これらの理由によって同

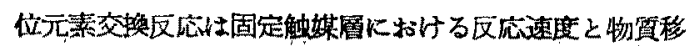
動との閶係をあきらか炕するに有力な手段を每えるるの と考穴られる。乞の一例として酸化クロ人触媒による気 態酸素々水蒸気との間の酸素原子の接触交換反応に対す る反応気体流速の影響を測定した。温度 $487 \sim 598^{\circ} \mathrm{C}$, 反応気体供給速度 30.1 136.1 cc N.T.P/sec Kおい. 気体流速の增加による反仗速度の增加は，1.3１.6 倍と なる。この実驗条件の籍国内に抋いて, 反必単位相当高 中に和ける移動単位相当高の割合楼\%を越えないか ら, 軸方向の拉散も影玮しているるのと考えられる。こ れらの結果と比較するため, Holm, Blue が水菜と重 水素との交換反応についてえた結果についても考察して み大た。***

\section{1. 粕霄}

同位元素交换氺灾の機作か工業的な触媒反応の機作と 直接関連を有夏る場合，たとえば鉄触媒による空素同位 元素の交煥反掂と丁ムモニフ合成反応とのことき，また マンガン酸化物触媒に上る酸素原子の交與反机々一酸化 㞸素の接触酸化反応とのことき場合において，実験室的 装置による交換反応の測定值より反応装置設計上の资料 をうることなならびに工業的反応塔に充㙞した触媒の作 用を少量の放射性同位元素を利用する交換反底によって 検定することを最終目的とし，擎者の一人が徉来化学的 に多数の研究を行ってきた気態酸素々水湴気との間の酸 素原子の接触交觟反応を工学的立場加ら取り上け゚て検討

\footnotetext{
* 昭和 29 年10月 7 日受理

** 名古扈大学工学部

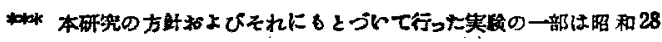

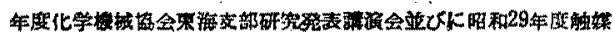

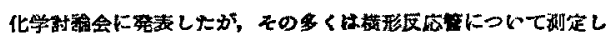

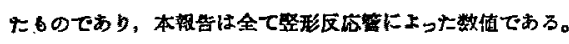

*****同位元来的标は平行でよく。
}

するため，ます湜合気体の流速と交换反応速度との閣保 をあきらかにしょらとしたるのである。交㪱反応は次の ことき多くの特徽を有するから，目的をする触媒反分を 直㨲に取り上り゙て基碐的な数值を実测するよりる，それ

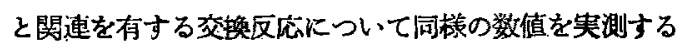
方が正確有利な場合が多いと考えら机る。

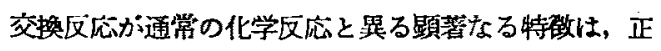
反応と逆反応とを区別しえないことである。すなわち，

$$
A X^{*}+B X \rightarrow A X+B X^{*}
$$

なる方向に起る反応と同時に，逆の方向に起る反応，

$$
A X+B X^{*} \rightarrow A X^{*}+B X
$$

るまた正常の反庶であって，同位元素效果を無視しうる 限り (1) 㭱応と対等に行われている。のみならず $A X$ と $B X, A X^{*}$ と $B X^{*}$ との間汇実験上熹めることの できない交換反応が行われている。これら総へての交換 反応を合算したものが真の交換反応速度 $R$ してこの其の交換反応速度には次のことき特改がある。 すなわち交换反応においては, 反応の進行にかかわらず 华学絸成には变化がないから触媒表面は化学的には吸着 平衡の状態なっって一定値を保ち、*****したがって物留 移動に対する抵抗たよび化学反応の抵抗に变化のない限 り，换言すれば触媒の活性度吅よび反応㙨作が变化しな い限り, 真の交涣広の速度は反応の進行にかかわらず 一定であり，その限りにおいて長短いかなる触媒層を通 過するとる微分仅応器と同一の結果がえられる事であ る。逆の見力からいえは真の反広速度 $R$ ，すなから微分 反応速度に変化が生したとすれば，物質移動速度または 化学反応䢞度に変化が生したことを指示することにな

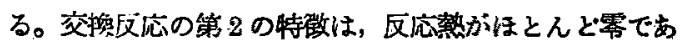
ることである。したがって外的条件による以外温度の变 動を考慮する必要がをく，問題を物買移動と真の化学反 応のみに限定しうる。また第 3 には，(1)(2) 両式で示 される反応の合計，すなわち見掛の交換反応速度は，こ れ時間的に追跡すれば1次反応として観測せられ，速 度解析が容易であることである。

交換反応の以上の特改は, 反应系が気液固のいすれの 相であってる，字た不均一禾であってる，反応経路が唯 1 種である限り常に成立することであるが，以下におい ては交换仪就が固体固定触媒層を通過する気体中にて行 
われる場合を考える。

\section{2. 交換反应の息度}

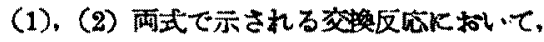
$A X+A X^{*}=N_{A}$ molecules $/ \mathrm{Cc}$, $A X^{*} /\left(A X+A X^{*}\right)=u_{A}$ $B X+B X^{*}=N_{B}$ molecules/cc, $B X^{*} /\left(B X+B X^{*}\right)=u_{B}$

そする。交献にあすかか原子が 1 分子中に』個以上ある

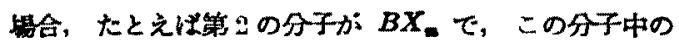
n個の $X$ 原子がすへて同一速度で效し5るものとす れは，このときは $B X_{n}+B X_{n}^{*}=n N_{B}$ とおく。これ恃 また分子を $B_{1 / n} X$ と考六 $B_{1 / n} X+B_{1 / n} X *=N_{B}$ とし

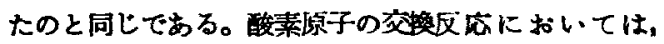

$\mathrm{O}_{2}, \mathrm{CO}_{2}, \mathrm{SO}_{2}$ 六と怢すべて $n=2$ である。しかるとき は. 見掛の反㢆速度と真の反心速度 $R$ との関係は, 律 速段階のいかんKかかからず次式によって与えられる。

$$
\begin{aligned}
-\frac{d u_{A} N_{A}}{d t} & =+\frac{d u_{B} N_{R}}{d t} \\
& =\left\{u_{A}\left(1-u_{B}\right)-u_{B}\left(1-u_{A}\right)\right\} R^{\prime} \\
& =\left\{u_{A}-u_{B}\right\} R^{\prime} .
\end{aligned}
$$

しかるに,

$$
\left(u_{A O}-u_{A}\right) N_{A}=\left(u_{B}-u_{B O}\right) N_{B}
$$

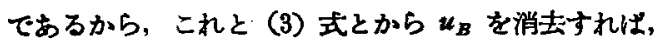

$$
-\frac{d u_{A}}{d t}=\left\{\left(\frac{1}{N_{A}}+\frac{1}{N_{B}}\right) u_{A}-\left(\frac{u_{B O}}{N_{A}}+\frac{u_{A O}}{N_{B}}\right)\right\} R^{\prime}
$$

となる。これは見脚の反分速度が1次となることを示し ているあのである。

- R' に対する表式をらるために，(4) 式を䅡分すれば,

$$
\begin{aligned}
u_{A}= & \frac{u_{A O} N_{A}+u_{B O} N_{B}}{N_{A}+N_{B}}+\frac{\left(u_{A O}-u_{B O}\right) N_{B}}{N_{A}+N_{B}} \exp \\
& \left\{-\frac{N_{A}+N_{B}}{N_{A} N_{B}} R^{\prime} \tau\right\}
\end{aligned}
$$

そなる。しかるに反度事 $x$ 性定教によって，

$$
x=\frac{u_{A O-u_{A}}}{u_{A O}-\left(u_{A O} N_{A}+u_{B O} N_{B}\right) /\left(N_{A}+N_{B}\right)}
$$

であるから，この $u_{A} K(5)$ 式を代入すれば，

$$
x=\left[1-\exp \left\{-\frac{N_{A}+N_{B}}{N_{A} N_{B}} R^{\prime} \tau\right]\right\}
$$

となり,したがって,

$$
R^{\prime}=\frac{N_{A} N_{B}}{\left(N_{A}+N_{B}\right) \tau}\{-\ln (1-x)\}
$$

となる。い度啳中における压力降下を無視すれば，

$$
\tau=-\frac{\pi D^{2} Z F_{e}}{4 F} \cdot \frac{273}{T}
$$

また

$$
R=R^{\prime} F_{e}(273 / T)
$$

ゆえK

$$
R=\frac{4 F}{\pi D^{2} Z} \cdot \frac{N_{A} N_{B}}{N_{A}+N_{B}} \cdot\{-\ln (1-x)\}
$$

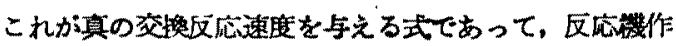
が不变である限り， $F ， D, Z$ の如何にかかからず，一 定温度においては一定值を与うへき性質のものである。

この式汢気体酸素々水蒸気との間の酸素原子の交换反 えについて、若干孯る形に招いて著者の 1 人”が古く上

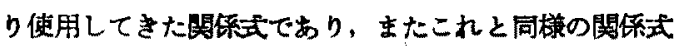
は最近 Norris (s) $^{2}$ Harris ${ }^{3)}$ らによっても馀ぜられてい る。

（8）式恃反矿単位数 $N_{R}$ と次の関係にある。

$$
\begin{aligned}
N_{R} & =\int_{u_{A}}^{u_{A} O} \frac{d u_{A}}{u_{A}-u_{A e}}=\ln \left(\frac{u_{A O}-u_{A E}}{u_{A}-u_{A E}}\right) . \\
& =-\ln \left(\begin{array}{c}
u_{A}-u_{A e} \\
u_{A O}-u_{A C}
\end{array}\right)=-\ln (1-x)
\end{aligned}
$$

したがって反分単位相当高 $H_{R}$ は，

$$
H_{R}=\frac{Z}{\bar{N}_{R}}=\frac{Z}{-\ln (1-x)}
$$

となる。よって（11）式を基楚としてでる反応条件の影 筥を吟味することができる。

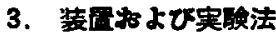

芰筇の概要は Fig. 1 のことくである。酸素は市販の 高压容器入りのものをそのま使用し，水蒸気は水の分 別蒸溜によって重酸素を腾縮した水を石英管傹き小さ いガス焻で蒸発して作る。反応管は内径 $16 \mathrm{~mm}$ 長さ $1 \mathrm{~m}$ の石英管であって、これを Fig. 2 と示すことく充堤す る。触媒はク口ム明ばんから出発して作った酸化クロム 1 に祄して苗木カォシン 3 を加え, 少量の水にて硬媡り し，これを径 $2 \mathrm{~mm}$ の細孔を有する真鏐製のプレスより 捧出し, 長さ $2 \mathrm{~mm}$ K切断して成型し, 自然乾煤の後 $110^{\circ}$ で乾燥したるのである。反応管に冭買後，酸素を通 しながら $500^{\circ}$ 亿約 7 時間加熱して前処理をする。

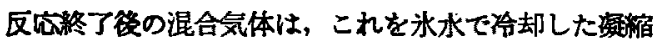
器で水蒸気を凝縮し，それる精製して，反度後の重酸素 による過剩櫁度を測定し，反応前の試料重酸素水のそれ と比較し, 反㐫率を知式によって求める。

$$
\text { 反店: } \mathrm{H}_{2} \mathrm{O}^{18}+\mathrm{O}^{19} \mathrm{O}^{16} \rightleftarrows \mathrm{H}_{2} \mathrm{O}^{16}+\mathrm{O}^{10} \mathrm{O}^{18}
$$$$
x=\left(\Delta \delta_{0}-\Delta \delta\right) /\left(\Delta \delta_{0}-\Delta \delta_{0}\right)
$$

\section{4. 更底䍿の王降下}

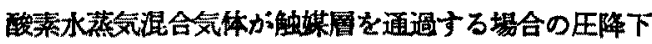

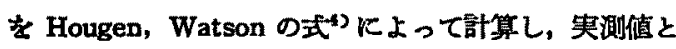
比较した。 Hougen, Watson の式を， 代力を maHg, 他をすべて C.G.S. 単位に挨算すれば。 

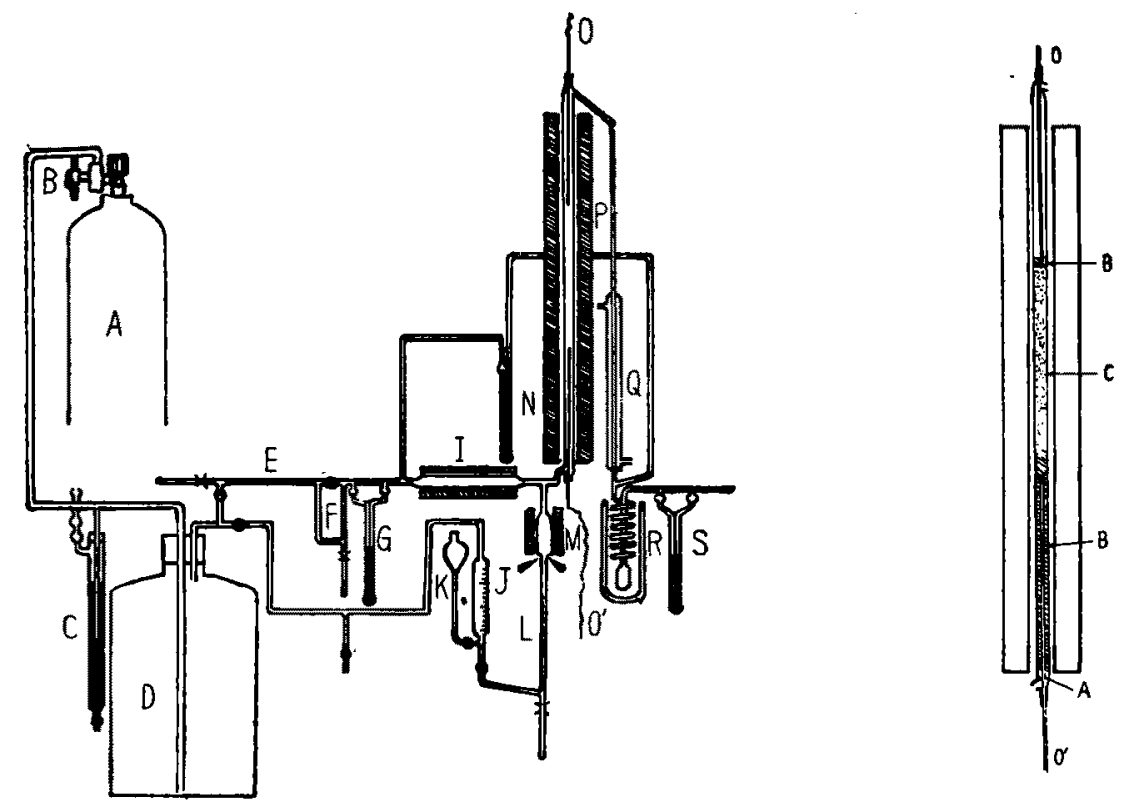

A : Oxygen Bomb, B, C, D : Pressure Regulator, E, F : Flow Rate Regulator (for High and Low Rate), G, S : Flow Meter, I : Preheater, K, J, L. : Reservoir and Flow Rate Regulator for Heavy Oxygen Water, $M$ : Evaporator, $N$ : Manometer, $0, \mathbf{O}^{\prime}:$ Thermocouples, $\mathbf{P}:$ Reactor, $\mathbf{Q}:$ Cooler, $\mathbf{R}:$ Condenser.

Fig. 1 Apparatus

\begin{abstract}
A : Glass Wool
B : Grantular Quartz

C: Catalyst Pellets

$0,0^{\prime}$ : Thermocouple
\end{abstract}

Fig. 2 Reactor

Table 1 Preessur drop through the bed

\begin{tabular}{|c|c|c|c|c|c|c|c|c|c|}
\hline $\begin{array}{r}G_{\mathrm{O}_{2} \times 10^{2}} \\
\mathrm{~g} / \mathrm{sec} \cdot \mathrm{cm}^{2}\end{array}$ & $\begin{array}{l}G_{\mathrm{H}_{2}} \mathrm{O} \times 10^{3} \\
g / \mathrm{sec}-\mathrm{cm}^{2}\end{array}$ & $\begin{array}{c}G \times 10^{3} \\
\mathrm{~g} / \mathrm{sec} \cdot \mathrm{cm}^{2}\end{array}$ & \begin{tabular}{l}
$T$ \\
$T$ \\
\hdashline
\end{tabular} & $\begin{array}{l}\mu_{\mathrm{m}} \times 10^{4} \\
\mathrm{~g} / \mathrm{sec} \cdot \mathrm{cm}\end{array}$ & $\begin{array}{c}M_{\mathrm{m}} \\
\mathrm{g} / \mathrm{mole}\end{array}$ & $\boldsymbol{f}_{\boldsymbol{D}}$ & $\begin{array}{c}\left(p_{0}^{2}-p^{3}\right) \times 10- \\
\text { mmHg }\end{array}$ & $\begin{array}{r}p_{0}-p \\
\text { mmHg }\end{array}$ & $\begin{array}{l}\Delta \not \text { (obs) } \\
m m H g\end{array}$ \\
\hline $\begin{array}{l}1.45 \\
1.45 \\
1.45 \\
2.19 \\
2.19\end{array}$ & $\begin{array}{l}0.38 \\
0.40 \\
0.42 \\
0.56 \\
0.58\end{array}$ & $\begin{array}{l}1.83 \\
1.85 \\
1.87 \\
2.75 \\
2.77\end{array}$ & $\begin{array}{l}811 \\
762 \\
851 \\
813 \\
765\end{array}$ & $\begin{array}{l}3.90 \\
3.58 \\
4.12 \\
3.92 \\
3.62\end{array}$ & $\begin{array}{l}27.5 \\
27.4 \\
27.3 \\
27.7 \\
27.5\end{array}$ & $\begin{array}{l}2.21 \\
2.06 \\
2.26 \\
1.66 \\
1.57\end{array}$ & $\begin{array}{l}2.74 \\
2.47 \\
3.10 \\
4.65 \\
4.21\end{array}$ & $\begin{array}{l}18 \\
16 \\
20 \\
30 \\
27\end{array}$ & $\begin{array}{l}18 \\
18 \\
20 \\
33 \\
30\end{array}$ \\
\hline $\begin{array}{l}2.19 \\
3.31 \\
3.32 \\
3.41 \\
3.46\end{array}$ & $\begin{array}{l}0.58 \\
0.82 \\
0.92 \\
0.87 \\
0.89\end{array}$ & $\begin{array}{l}2.77 \\
4.13 \\
4.24 \\
4.28 \\
4.35\end{array}$ & $\begin{array}{r}854 \\
839 \\
858 \\
-\quad 767 \\
810\end{array}$ & $\begin{array}{l}4.13 \\
4.10 \\
4.16 \\
3.65 \\
3.89\end{array}$ & $\begin{array}{l}27.6 \\
27.7 \\
27.4 \\
27.6 \\
27.6\end{array}$ & $\begin{array}{l}1.72 \\
1.29 \\
1.28 \\
1.16 \\
1.20\end{array}$ & $\begin{array}{l}5.14 \\
8.41 \\
9.09 \\
7.45 \\
8.40\end{array}$ & $\begin{array}{l}33 \\
53 \\
58 \\
47 \\
53\end{array}$ & $\begin{array}{l}34 \\
55 \\
58 \\
50 \\
54\end{array}$ \\
\hline $\begin{array}{l}3.49 \\
4.78 \\
4.72 \\
4.80 \\
4.72\end{array}$ & $\begin{array}{l}0.90 \\
1.10 \\
1.17 \\
1.22 \\
1.31\end{array}$ & $\begin{array}{l}4.39 \\
5.88 \\
5.89 \\
6.02 \\
6.03\end{array}$ & $\begin{array}{l}866 \\
828 \\
853 \\
773 \\
829\end{array}$ & $\begin{array}{l}4.23 \\
4.04 \\
4.16 \\
3.67 \\
3.99\end{array}$ & $\begin{array}{l}27.6 \\
27.8 \\
27.7 \\
27.7 \\
27.4\end{array}$ & $\begin{array}{l}1.26 \\
1.00 \\
1.02 \\
0.92 \\
0.97\end{array}$ & $\begin{array}{r}9.64 \\
12.95 \\
13.70 \\
11.70 \\
13.48\end{array}$ & $\begin{array}{l}61 \\
81 \\
85 \\
73 \\
84 .\end{array}$ & $\begin{array}{l}60 \\
80 \\
83 \\
75 \\
83\end{array}$ \\
\hline $\begin{array}{l}5.86 \\
6.62 \\
6.73\end{array}$ & $\begin{array}{l}1.59 \\
1.50 \\
1.65\end{array}$ & $\begin{array}{l}7.45 \\
8.12 \\
8.38\end{array}$ & $\begin{array}{l}827 \\
871 \\
765\end{array}$ & $\begin{array}{l}3.98 \\
4.32 \\
3.65\end{array}$ & $\begin{array}{l}27.5 \\
28.0 \\
27.8\end{array}$ & $\begin{array}{l}0.84 \\
0.83 \\
0.73\end{array}$ & $\begin{array}{l}17.61 \\
21.57 \\
17.79\end{array}$ & $\begin{array}{l}108 \\
131 \\
109\end{array}$ & $\begin{array}{l}100 \\
120 \\
114\end{array}$ \\
\hline
\end{tabular}

$$
p_{0}^{2}-p^{2}=186.3 \frac{f_{D} G^{2} a_{v} T Z}{F_{e}^{1 \cdot 7} M_{m}}
$$

となる。

触媒層高 $24 \mathrm{~cm}$ ，これに前後に搟入した石英粒子層を 考慮に入れて $Z=36 \mathrm{~cm}$ であるから,

$$
p_{0}^{2}-p^{2}=1.260 \times 10^{6} \frac{f_{D} G^{2} T}{M_{m}}
$$

そなる。また modified Reynold's number, $N_{\text {Rep }}=$ $G / a_{v} \mu=2 \sim 10$ であって, この䇺囲において,

$$
f_{D}=3.8\left(N_{R e p}\right)^{-0.1}
$$


として㙄算した。Table 1 は計算值と実験値とを比較し たものである。両者が大体よく一致していることは，強

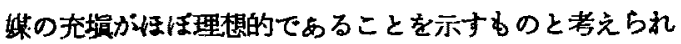
る。

\section{5. 真の反㭛速度に対する流速の影}

酸素·水蒸気湿合気体中の両者の容棈比を, 酸菜: 水 堂気= $: 1$ とし, 全匤を $1 \mathrm{~atm}$ とすれば,

$$
\frac{N_{A} N_{B}}{N_{A}+N_{B}}=2.69 \times 10^{19} \cdot \frac{2 \alpha}{(2 \alpha+1)(\alpha+1)}
$$

となるから，(8) 式によって，

$R=6.84, \times 10^{18} \frac{F}{D^{2} Z} \frac{\alpha}{(2 \alpha+1)(\alpha+1)}\{-\ln (1-x)\}$

\section{となる。}

Table 2，2〜9行は，㬰験結果の主要なるあのにつ いて，実殹㨋条件およびそれによって測定した反応率， ならびにそれより（14）式によって計算した全交換反底 速度 $R$ を示したものである。 $\alpha$ の平均値， $\alpha_{\text {mean }}=$ 2.18 であって，その偏盖は最す大きいすので約20\%で あるが，多くはる\%程度以内保たれている。のの变動

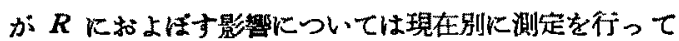
いるが, 上記変動の範囲では顕著な影響はないるのと推
定している。反底管の大きさ：D=1.6cm, Exp. No. $1 \sim 19$ は $Z=24.0 \mathrm{~cm}, 29 \sim 36$ は $Z=23.5 \mathrm{~cm}, 37 \sim 51$ は $Z=23.8 \mathrm{~cm}$ である。

Fig. 3 は $\log R$ vs. $1 / T$ を图示したものである。图 に見られることく，個々の測定点の变動はかなり大きく 反応気体供給速度 $F$ の変化による差異は個々の測定点 相互間については竞にんと誤差籁囲内に入るが，総括的

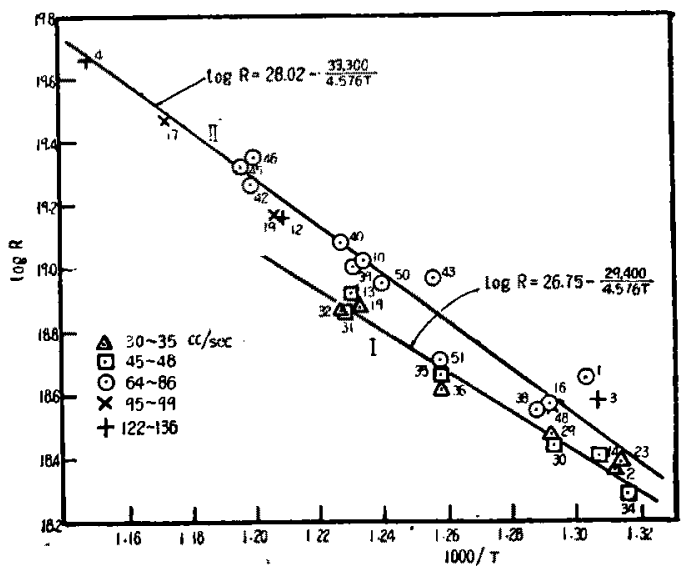

Fig. 3 Effect of temperature and feed rate upon the exchange reaction rate.

Table 2 Reaction rate data.

\begin{tabular}{|c|c|c|c|c|c|c|c|c|c|c|c|c|c|c|}
\hline $\begin{array}{c}1 \\
x p . \text { No. }\end{array}$ & $\begin{array}{l}2 \\
\text { TemI } \\
{ }^{\circ} \mathrm{C}\end{array}$ & $\begin{array}{c}3 \\
v_{\mathrm{O}_{2}} \\
\mathrm{cc} / \mathrm{sec}\end{array}$ & $\begin{array}{c}4 \\
v_{\mathrm{H}_{2} \mathrm{O}} \\
\mathrm{cc} / \mathrm{sec}\end{array}$ & $\begin{array}{c}5 \\
\mathrm{cc} / \mathrm{sec}\end{array}$ & $\begin{array}{c}6 \\
G \times 10^{2} \\
g / \mathrm{sec}^{2} \mathrm{~cm}^{3}\end{array}$ & ${ }_{\alpha}^{7}$ & $\begin{array}{c}8 \\
-\ln (1-x) \\
\text { atom }\end{array}$ & $\begin{array}{c}9^{9} \\
R \times 10^{-18} \\
/ \mathrm{sec} \cdot \mathrm{cc}\end{array}$ & $\begin{array}{c}10 \\
\mathrm{~m}_{\mathrm{m}} \times 10^{4} \\
/ \mathrm{sec} \cdot \mathrm{cm} \\
\ldots \ldots \ldots \ldots\end{array}$ & $\begin{array}{c}11 \\
D_{n z} \\
\mathrm{~cm}^{2} / \mathrm{sec} \\
\ldots .\end{array}$ & $\begin{array}{r}12 \\
D_{n} G \\
A_{m}\end{array}$ & $\begin{array}{c}13 \\
\frac{\mu_{m}}{\rho_{m} D_{m}}\end{array}$ & $\begin{array}{c}14 \\
H_{T} \\
\mathrm{~cm}\end{array}$ & $\begin{array}{c}15 \\
H_{\boldsymbol{R}} \\
\mathrm{cm} \\
\ldots \ldots\end{array}$ \\
\hline $\begin{array}{r}11 \\
2 \\
36 \\
32 \\
33\end{array}$ & $\begin{array}{l}538 \\
489 \\
522 \\
542 \\
488\end{array}$ & $\begin{array}{l}20.5 \\
20.5 \\
23.2 \\
23.0 \\
23.2\end{array}$ & $\begin{array}{r}9.6 \\
10.0 \\
9.8 \\
10.1 \\
11.2\end{array}$ & $\begin{array}{l}30.1 \\
30.5 \\
33.0 \\
33.1 \\
34.4\end{array}$ & $\begin{array}{l}1.84 \\
1.85 \\
2.04 \\
2.03 \\
2.10\end{array}$ & $\begin{array}{l}2.14 \\
2.05 \\
2.38 \\
2.28 \\
2.07\end{array}$ & $\begin{array}{l}1.732 \\
0.519 \\
0.929 \\
1.555 \\
0.470\end{array}$ & $\begin{array}{l}7.49 \\
2.32 \\
4.10 \\
7.34 \\
2.42\end{array}$ & $\begin{array}{l}3.90 \\
3.58 \\
3.83 \\
3.94 \\
3.59\end{array}$ & $\begin{array}{l}0.928 \\
0.844 \\
0.896 \\
0.933 \\
0.844\end{array}$ & $\begin{array}{l}11.6 \\
12.7 \\
13.1 \\
12.6 \\
14.3\end{array}$ & $\begin{array}{l}1.018 \\
0.969 \\
1.003 \\
1.020 \\
0.969\end{array}$ & $\begin{array}{r}0.112 \\
.117 \\
.119 \\
.118 \\
.123\end{array}$ & $\begin{array}{l}13.9 \\
46.3 \\
25.3 \\
15.1 \\
50.0\end{array}$ \\
\hline $\begin{array}{l}29 \\
13 \\
14 \\
.35 \\
31\end{array}$ & $\begin{array}{l}501 \\
540 \\
492 \\
522 \\
541\end{array}$ & $\begin{array}{l}23.5 \\
30.8 \\
30.8 \\
31.4 \\
31.8\end{array}$ & $\begin{array}{l}11.4 \\
14.1 \\
14.6 \\
14.4 \\
14.5\end{array}$ & $\begin{array}{l}34.9 \\
44.9 \\
45.4 \\
45.8 \\
45.3\end{array}$ & $\begin{array}{l}2.13 \\
2.75 \\
2.77 \\
2.81 \\
2.84\end{array}$ & $\begin{array}{l}2.06 \\
2.18 \\
2.11 \\
2.18 \\
2.19\end{array}$ & $\begin{array}{l}0.565 \\
1.308 \\
0.387 \\
0.674 \\
1.058\end{array}$ & $\begin{array}{l}2.95 \\
8.35 \\
2.54 \\
4.51 \\
7.13\end{array}$ & $\begin{array}{l}3.66 \\
3.92 \\
3.62 \\
3.80 \\
3.93\end{array}$ & $\begin{array}{l}0.864 \\
0.888 \\
0.845 \\
0.900 \\
0.929\end{array}$ & $\begin{array}{l}14.3 \\
17.2 \\
18.8 \\
18.1 \\
17.7\end{array}$ & $\begin{array}{l}0.981 \\
1.066 \\
0.973 \\
0.998 \\
1.034\end{array}$ & $\begin{array}{l}.124 \\
.146 \\
.145 \\
.145 \\
.146\end{array}$ & $\begin{array}{l}41.5 \\
18.3 \\
62.1 \\
34.9 \\
22.3\end{array}$ \\
\hline $\begin{array}{l}30 \\
34 \\
48 \\
45 \\
40\end{array}$ & $\begin{array}{l}500 \\
487 \\
501 \\
563 \\
542\end{array}$ & $\begin{array}{l}31.7 \\
31.9 \\
45.0 \\
43.5 \\
43.2\end{array}$ & $\begin{array}{l}15.8 \\
16.0 \\
19.3 \\
20.9 \\
21.4\end{array}$ & $\begin{array}{l}47.5 \\
47.9 \\
64.3 \\
64.4 \\
64.6\end{array}$ & $\begin{array}{l}2.88 \\
2.90 \\
3.96 \\
3.93 \\
3.92\end{array}$ & $\begin{array}{l}2.01 \\
1.99 \\
2.33 \\
2.08 \\
2.02\end{array}$ & $\begin{array}{l}0.374 \\
0.265 \\
0.414 \\
2.254 \\
1.262\end{array}$ & $\begin{array}{r}2.70 \\
1.93 \\
3.69 \\
21.29 \\
12.15\end{array}$ & $\begin{array}{l}3.65 \\
3.58 \\
3.70 \\
4.03 \\
3.90\end{array}$ & $\begin{array}{l}0.860 \\
0.840 \\
0.864 \\
0.969 \\
0.933\end{array}$ & $\begin{array}{l}19.3 \\
19.9 \\
26.2 \\
23.9 \\
24.6\end{array}$ & $\begin{array}{l}0.962 \\
0.973 \\
0.982 \\
1.037 \\
1.024\end{array}$ & $\begin{array}{l}.147 \\
.150 \\
.178 \\
.175 \\
.177\end{array}$ & $\begin{array}{l}62.9 \\
88.8 \\
57.5 \\
10.6 \\
18.9\end{array}$ \\
\hline $\begin{array}{c}51 \\
1 \\
10 \\
42 \\
38\end{array}$ & $\begin{array}{l}522 \\
494 \\
537 \\
561 \\
503\end{array}$ & $\begin{array}{l}43.7 \\
48.0 \\
48.8 \\
54.8 \\
54.2\end{array}$ & $\begin{array}{l}24.2 \\
21.8 \\
22.1 \\
21.0 \\
22.4\end{array}$ & $\begin{array}{l}67.9 \\
69.8 \\
70.9 \\
75.8 \\
76.6\end{array}$ & $\begin{array}{l}4.07 \\
4.28 \\
4.35 \\
4.73 \\
4.75\end{array}$ & $\begin{array}{l}1.81 \\
2.20 \\
2.21 \\
2.61 \\
2.42\end{array}$ & $\begin{array}{l}0.479 \\
0.454 \\
1.058 \\
1.861 \\
0.337\end{array}$ & $\begin{array}{r}5.09 \\
4.49 \\
10.60 \\
18.39 \\
3.51\end{array}$ & $\begin{array}{l}3.72 \\
3.65 \\
3.89 \\
4.09 \\
3.71\end{array}$ & $\begin{array}{l}0.900 \\
0.848 \\
0.925 \\
0.965 \\
0.864\end{array}$ & $\begin{array}{l}25.6 \\
28.7 \\
27.4 \\
28.3 \\
31.4\end{array}$ & $\begin{array}{l}0.993 \\
0.980 \\
1.013 \\
1.031 \\
0.980\end{array}$ & $\begin{array}{r}.178 \\
.189 \\
.187 \\
.193 \\
.199\end{array}$ & $\begin{array}{l}49.7 \\
52.9 \\
22.7 \\
12.8 \\
70.7\end{array}$ \\
\hline $\begin{array}{l}43 \\
39 \\
46 \\
50 \\
17\end{array}$ & $\begin{array}{l}\mathbf{5 2 3} \\
\mathbf{5 3 9} \\
\mathbf{5 6 0} \\
\mathbf{5 3 3} \\
\mathbf{5 8 0}\end{array}$ & $\begin{array}{l}54.8 \\
54.1 \\
56.7 \\
57.1 \\
66.5\end{array}$ & $\begin{array}{l}23.1 \\
24.8 \\
25.2 \\
28.5 \\
29.2\end{array}$ & $\begin{array}{l}77.9 \\
78.9 \\
81.9 \\
85.6 \\
95.7\end{array}$ & $\begin{array}{l}4.81 \\
4.83 \\
5.06 \\
5.19 \\
5.89\end{array}$ & $\begin{array}{l}2.37 \\
2.18 \\
2.21 \\
2.00 \\
2.28\end{array}$ & $\begin{array}{l}0.870 \\
0.890 \\
1.938 \\
0.705 \\
2.207\end{array}$ & $\begin{array}{r}9.31 \\
10.08 \\
22.62 \\
9.03 \\
29.36\end{array}$ & $\begin{array}{l}3.84 \\
3.91 \\
4.03 \\
3.85 \\
4.15\end{array}$ & $\begin{array}{l}0.904 \\
0.928 \\
0.964 \\
0.916 \\
1.000\end{array}$ & $\begin{array}{l}30.7 \\
30.3 \\
30.1 \\
33.0 \\
34.7\end{array}$ & $\begin{array}{l}0.997 \\
1.018 \\
1.035 \\
1.018 \\
1.051\end{array}$ & $\begin{array}{l}.198 \\
.199 \\
.201 \\
.210 \\
.221\end{array}$ & $\begin{array}{l}27.3 \\
26.7 \\
12.3 \\
33.8 \\
10.9\end{array}$ \\
\hline $\begin{array}{r}16 \\
19 \\
12 \\
4 \\
3\end{array}$ & $\begin{array}{l}500 \\
556 \\
554 \\
598 \\
492\end{array}$ & $\begin{array}{l}67.8 \\
66.6 \\
82.5 \\
93.1 \\
94.8\end{array}$ & $\begin{array}{l}30.5 \\
32.8 \\
39.7 \\
37.4 \\
41.3\end{array}$ & $\begin{array}{r}98.3 \\
99.4 \\
122.2 \\
130.5 \\
136.1\end{array}$ & $\begin{array}{l}6.03 \\
6.04 \\
7.45 \\
8.12 \\
8.38\end{array}$ & $\begin{array}{l}2.22 \\
2.03 \\
2.08 \\
2.49 \\
2.30\end{array}$ & $\begin{array}{l}0.257 \\
1.005 \\
0.816 \\
2.689 \\
0.202\end{array}$ & $\begin{array}{r}3.57 \\
14.72 \\
14.51 \\
46.53 \\
3.81\end{array}$ & $\begin{array}{l}3.67 \\
3.99 \\
3.98 \\
4.32 \\
3.65\end{array}$ & $\begin{array}{l}0.860 \\
0.957 \\
0.952 \\
1.032 \\
0.888\end{array}$ & $\begin{array}{l}40.3 \\
37.1 \\
45.9 \\
46.1 \\
56.2\end{array}$ & $\begin{array}{l}0.981 \\
1.035 \\
1.035 \\
1.073 \\
0.932\end{array}$ & $\begin{array}{l}.231 \\
.228 \\
.259 \\
.266 \\
.272\end{array}$ & $\begin{array}{r}93.5 \\
23.9 \\
29.4 \\
8.9 \\
119\end{array}$ \\
\hline
\end{tabular}


な傾向としては $\boldsymbol{F}$ の小なるすの程 $\boldsymbol{R}$ が小さい。これ をFが48以下のるのと64 以上のbのとに分って近似 直線を引いてみれば，図中のI括よびルとなる。雨直線

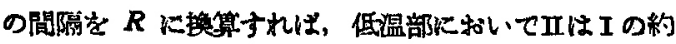
1.3 倍, 高温部において約 1.6 倍となっている。

\section{6. 結果の者蜜}

酸菜の分压 $(2.18 / 3.18)=0.686 \mathrm{~atm}$ においてて, 固体

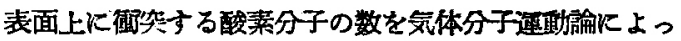

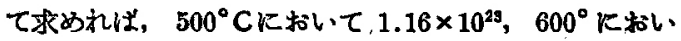
て $1.10 \times 10^{23}$ molecules/sec である。触媒層 $1 \mathrm{cc}$ 中の 触媒の外部表面稰は， $a_{v}=21.6 \mathrm{~cm}^{2} / \mathrm{cc}$ であるから， これに衝突する酸素分子の数を原子数で表わせば，䄪

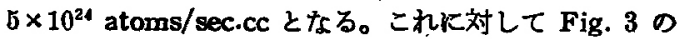
直線 I，四の年学る頻度因子 $5.6 \times 10^{26}$ および $1.05 \times$ $10^{28}$ は 100 および 2,000倍大きい值となっている。この ことは内部表面が大きく作用していることを示するので あって，このことからる图の湘定温度筑囲内に掠いては 境脱抔散が律嗃段階ではないことが推定される。

反底抵抗のうち境膛抵抗が占的る割合と反底気体の留

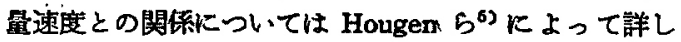
く述ペられている。これにるとすいて移動単位相当高 $\boldsymbol{H}_{\boldsymbol{x}}$ を算出し，また（10）式によって求めた反応単位相 当高 $H_{B}$ と比較してみると Table 2 の 14, 15行のこ そくなる。また10〜13 行は $H_{\boldsymbol{T}}$ の計算に使用した恒 数を示したるのである。 $j$ 因子の計算には $j_{d}=1.82$ $\left(D_{p} G / 1 /\right)^{-0.51}$ を用いた。表に見られることく，实験し た気体流速および温度の籍围内においてては $H_{T}$ は $H_{R}$ の数\%以下娍きない。 $H_{T}$ と $H_{R}$ との比から外括すれ は，粎 $650^{\circ} \mathrm{C}$ 秘いて $H_{T}$ が $H_{R}$ の $10 \%$ に達する。

反広速度に対する反応気体流速の影烸は，触媒罣の末 端㹝果拉よびトンネル效果 (channeling)ならびに磨中 における生力降下の影響を一応除外すれば，上述の気膜

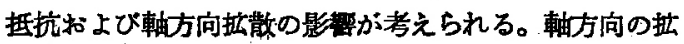
散を簡単に考察するために，触媒層を軸方向に $n$ 個の相 等しい区間に切断し，各区間内では気体が完全に温合し， 区間相互間では混合坟全くないるのとする。換言すれば 反応層をあたかるn個の連続タンク反応器のことく考 える。しかるときは反応物の反応前後における浱度の比 すなわち今の場合 $1-x$ は， $(1+k \tau / n)$ - Kて表わさ れる。たたし $k$ は 1 次反応の速度恒数である。したが

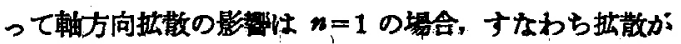

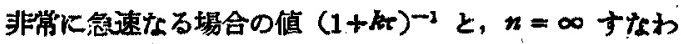
ち完全なビストン流と考えられる場合の傎，

$$
\lim _{n \rightarrow \infty}(1+k \tau / n)^{-n}=e^{-k \tau}
$$

との両極端の中間のどこがスることとなる。け立こた ろみに低洗速部分の 23 をとって禹者の関係を梌してみ ると Table 3 のことくなる。すなわち低流速の場合に おいて，反応臂中の反度気体か完全に温合していたすの

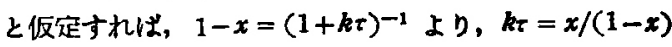
となり $k \tau$ が求少られる。このよろな反高速度恒数 $k$ お よび接虽時間 てを以って，反応が完全なビストン流と

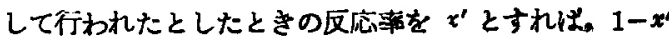

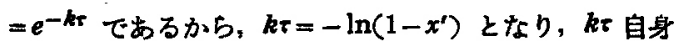
が後者の場合の反広単位数を表わすことになる。したが って Table 3 の第 4 行と第 2 行との比はピストン流の 場合の反応速度と完全湿合の場合の反応速度の比を与立 る。この比は第 5 行に示したことく, 区応率の少い方で 1.3，多い方で2.7倍近くに達する。

この計算例は極端場合についてであるが，軸方闭の

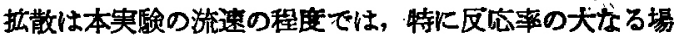
合においてて，無視しえないわのと考えられる。さらに， 流速が大なる場合には圷力降下が大なるために，接触時 間こは（8）式を用いて計算したるのよりる大となり， したがって（8）式を用いてえられた（14）式の速度 $R$ か真の值よりも大となることす教えられる。

Table 3 Effect of longitudinal diffusion

\begin{tabular}{ccccc} 
Exp. No. & $-\ln (1-x)$ & $x$ & $k=x /(1-x)$ & {$[k \pi /-\ln (1-x)]$} \\
\hline 2 & 0.519 & 0.405 & 0.681 & 1.31 \\
29 & 0.566 & 0.432 & 0.761 & 1.34 \\
32 & 1.556 & 0.789 & 3.74 & 2.40 \\
11 & 1.732 & 0.823 & 4.65 & 2.68 \\
\hline
\end{tabular}

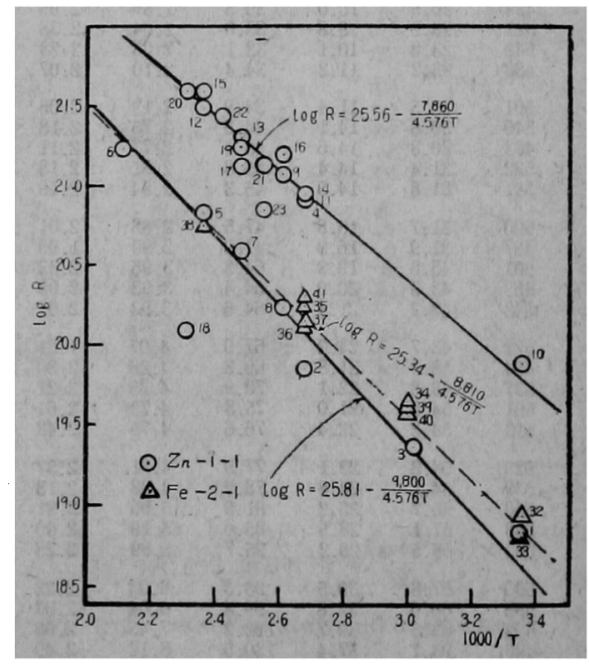

Fig. 4 Rate of exchange reaction between hydrogen and deuterium (Holm, Blue) 
以上の結果と比敦するため, Holm, Blue ${ }^{6)}$ が酸化互

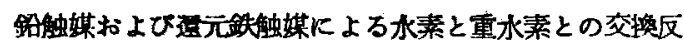
馆についてえた数值に，本報货の方法を適用してみた。

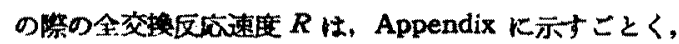

$$
\left.R=1.344 \times 10^{10} \text { (S. V. }\right)\{-\ln (1-x)\}
$$

で与えられる。Holm, Blue の報交の Table V の数值 を用いて $R$ 計算し， $\log R$ vs. $1 / T$ を图示すれぱ Fig. 4 のことくなる。図中の测定点に附した数值は， Holm, Blue の Table V の实蜍值化上から順次潘号 をつけて表わしたるのである。これに上れば番号 4, 9，18，23のbのを馀いては大体值線関係を示してお。

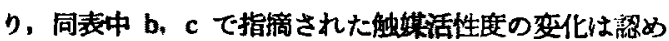
られデ，かえって酸化西触媒については S.V.の小さ いNo. 9 以下の実験と, S.V.の大きいNo. 10 以上と 火区分されている。凮者の美は $R$ の数值にして約10㥉 であり，一方この場合す $H_{r}$ は $H_{n}$ の数\%以下に過き

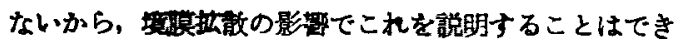
ない。この実乘恃こく小さい容皘の触媒尿についてて行わ れたるのであるから，螌媒算の末端炏果のあることも考 之られる。さらに根本的炕触媒活性度白身がどの程度 に一定に保たれたかる審かでない。

\section{7. 結敦}

クロム酸化物とカオリンとを湿合成形した触媒による 気態酸素と水蒸気との間の酸素原子交換反应の速度を，

温度 $487 \sim 698^{\circ} \mathrm{C}$, 反応気体供給速度 $30.1 \sim 136.1 \mathrm{cc}$ N.T.P/sec の籍囲で測定した。反讼気体の流通による

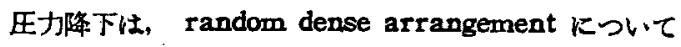
Hougen らが与えた式と最く一致した。反店気体の流速 变化に上る反広速应の变化は低温部に批いて約 1.3 倍,

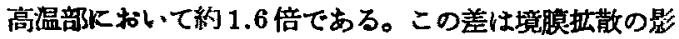

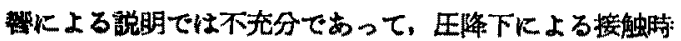
間の帘化にもとすく固定誤差と軸方向の拉散の影鹤によ って説明し5る。Holm, Blue が水素と重水素との交 換反応沉つ、て行った数值を解析した結果も同一の傾向 を示した。

\section{Appendix}

水素々重水素との交換反应は，生成物が同種の分子で あることによって第2節の速度式の誘䢙をそのまま总用 しがたいっっって次のことくして洘察を進める。

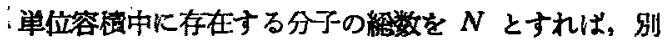

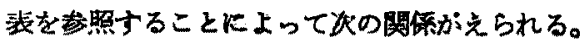

$$
\begin{aligned}
-\frac{d u_{\mathrm{D}_{2}} N}{d t} & =+\frac{d u_{\mathrm{HD}} N}{d t} \\
& =\left(2 u_{\mathrm{D}_{2}} u_{\mathrm{H}_{2}}-2 u_{\mathrm{HD}}^{2}\right) R^{\prime}
\end{aligned}
$$

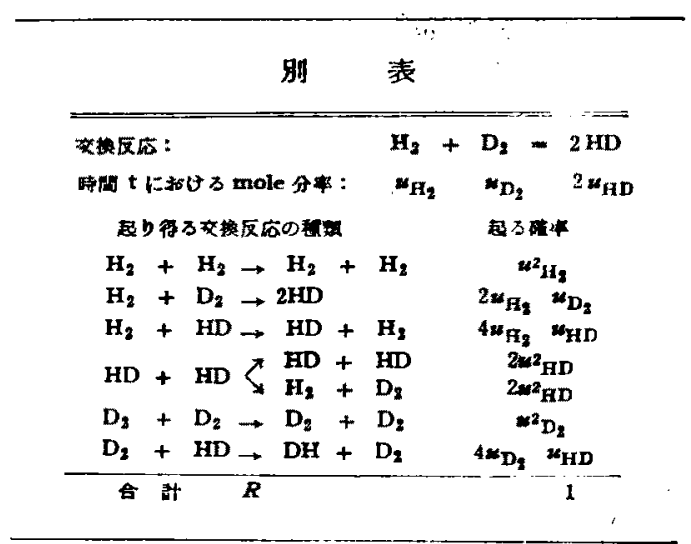

$$
\begin{aligned}
& u_{\mathrm{HD}}=u_{\mathrm{D}_{2}, \mathrm{O}}-u_{\mathrm{D}_{2}} \\
& u_{\mathrm{F}_{2}}=1-u_{\mathrm{D}_{2}}-2 u_{\mathrm{HD}}=1+u_{\mathrm{D}_{2}}-2 u_{\mathrm{D}_{1}, 0}
\end{aligned}
$$

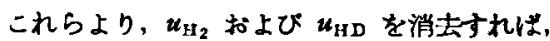

$$
-\frac{d u_{\mathrm{D}_{2}}}{d t}=2\left(u_{\mathrm{D}_{2}}-u_{\mathrm{D}_{2}, 0}^{2}\right) \frac{R^{\prime}}{N}
$$

これを棈分し, $t=0$ Kおいてて $u_{D_{2}}=u_{D_{2}, 0}$ なる関保 によって粗分恒数を決定すれば

$$
R^{\prime}=\frac{N}{2 \tau} \ln \frac{u_{\mathrm{D}_{2}, 0}^{2}-u_{\mathrm{D}_{2}, 0}}{u_{\mathrm{D}_{2}, 0-u_{\mathrm{D}_{2}}}^{2}}
$$

これに,

$$
\tau=\frac{v F_{e}}{F} \cdot \stackrel{273}{T}, \quad R=R^{\prime} F e \cdot \stackrel{273}{T}
$$

を代入すれば、

$$
\begin{aligned}
& R=\frac{N F}{2 v} \cdot \ln \frac{u^{2} \mathrm{D}_{2}, 0-u_{\mathrm{D}_{2}, 0}}{u^{2} \mathrm{n}_{2}, 0-u_{\mathrm{D}_{2}}}
\end{aligned}
$$

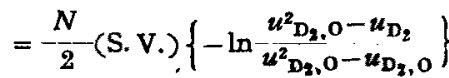

となる。いま平衡亘数を，

$$
\frac{\left(2 u_{\mathrm{RD}, e}\right)^{a}}{u_{\mathrm{B}_{2}, e} \cdot u_{\mathrm{B}_{2} \cdot e}}=K \approx 4
$$

としこれに前にえた関釈によって $u_{\mathrm{HD}, e}, u_{\mathrm{H}_{2}, e}$ を消 去すれば，

$$
\left(u_{D_{2}}-u_{D_{2}, e}\right)^{2}=\left(1+u_{D_{2}, e}-2 u_{D_{2}, 0}\right) u_{D_{2}, e}
$$

これとよって $u^{2} \mathrm{D}_{2,0}=u_{\mathrm{D}_{2, e}}$ なる関係が兄られるから、

$$
\begin{aligned}
R & =-\frac{N}{2} \text { (S.V.) }\left\{-\ln \frac{u_{D_{2}}-u_{D_{2, e}}}{u_{D_{2}, 0}-u_{D_{2}, e}}\right\} \\
& =\frac{N}{2} \text { (S.v.) }\{-\ln (1-x)\}
\end{aligned}
$$

となる。全圧 $1 \mathrm{~atm}$ の場合 $N=2.687 \times 10^{13}$ である。

\section{Nomenclature :}

$A, B, X=$ Atom or atomic group, resp.

$$
X^{*} \quad=\text { lsotope of } X
$$


$D=$ Inner diameter of reactor, $\mathrm{cm}$

$D_{p}=$ Effective particle diameter $=0.2 \vee \overline{1.5}$ $=0.245 \mathrm{~cm}$

$D_{m}=$ Average diffusivity, $\mathrm{cm}^{2} / \mathrm{sec}$

$F=$ Feed rate, cc N.T.P./sec

$F_{c}=$ Void fraction $=1-\left(P_{B} / P_{p}\right)=0.280$

$G=$ Mass velocity, $\mathrm{g} / \mathrm{sec} \cdot \mathrm{cm}^{2}$

$H_{R}=$ Height of a reactor unit, $\mathrm{cm}$

$H_{T}=$ Height of a transfer unit, $\mathrm{cm}$

$M_{w}=$ Mean molecular weight

$N=$ Number of molecules per unit volume (N. T.P.)

$\boldsymbol{R}=$ Total exchange reaction rate, number of exchange per unit time per unit volume of reactor

$R^{\prime}=$ Total exchange reaction rate, number of exchange per unit time per unit volume of feedgas (N.T.P.)

$T=$ Temperature of catalyst bed, ${ }^{\circ} \mathrm{K}$

$Z=$ Height of catalyst bed, $\mathrm{cm}$

$a_{v}=$ Particle area per unit volume of catalyst bed, $\mathrm{cm}^{2} / \mathrm{cc}$

$u=$ Atomic fraction of isotope $x$ = Conversion, net fraction of exchange to equilibrium

$\Delta \delta=$ Excess density of heavy oxygen water

$\rho_{B}=$ Bulk density of catalyst bed $=0.735 \mathrm{~g} / \mathrm{cc}$

$\rho_{p}=$ Particle density of catalyst $=1.020 \mathrm{~g} / \mathrm{cc}$

$P_{0}=$ Solid density of catalyst $=3.275 \mathrm{~g} / \mathrm{cc}$

$\tau=$ Contact time, sec

$\mu_{m}=$ Mean viscosity. $\mathrm{g} / \mathrm{sec} \cdot \mathrm{cm}$

Suffix

$0=$ values at feed

$e=$ values at equilibrium

\section{Literature :}

1) Morita, N.: Bull. Chem. Soc. Japan, 15,166 (1940) 禁田：日化, 62, 74 (1941)

2) Norris, T.H.: J. Phyp. \& Colloid Chem., 54, in (1950)

3) Harris, G. M. : Trans, Faraday Soc., 57, 716 (1951)

4) Hougen, O. A., \& Watson, K. M. : "Chemical Process Principles"" p.1019 (1950)

5) Hougen, O.A., and Watson, K. M. : ibid., p. 982 Young, K. H., and Hougen, O. A. : Chem, Eng. Progr. 46, $146(1950)$; Hougen, O. A.: Z. Elektrochem., 59 479 (1953): Rogers, J.D.: Ind. Eng. Chem., 45, 1574 (1953)

6) Holm, V.C.F., and Blue, R.W.: ibid., 4, 107 (1952)

\title{
Dependence of the Isotopic Exchange Reaction Rate in Catalytic Bed upon the Rate of Feed Gases
}

\author{
Sadahiro Sakata* and Noriyoshi Morita*
}

\section{Summary}

The rate of the exchange of oxygen atoms between gaseous oxygen and water vapor was examined under various conditions ranging between $487-598^{\circ} \mathrm{C}$ of temperature and $30.1-136.1 \mathrm{cc} /$ sec of feed rate. Cylindrical pellets of height and diameter each equal to $0.2 \mathrm{~cm}$ were prepared from the mixture of $1: 3$ of chromic oxide and the Naegi kaolin, and packed in a silica tube of $1.6 \mathrm{~cm}$ inside diameter by $23.5-24.0 \mathrm{~cm}$ height. Random dense arrangement of the bed was measured by the pressure drop of the gas flowing through the tube.

The relations between the logarithms of the total exchange reaction rate $R$ and the reciprocal of the temperature $T$ in ${ }^{\circ} \mathrm{K}$ are plotted in the Fig. 3. These plots are for convenience sake, divided into two classes, one belonging to the lower feed rate less than $48 \mathrm{cc} / \mathrm{sec}$ and the other to the higher feed rate above $64 \mathrm{cc} / \mathrm{sec}$. The values of $R$ in these two classes differ by the factor of about 1.3 at lower temperature and 1.6 at higher temperature. These differences are explained by the effects of mass-transfer of the gas film, of longitudinal diffusion of reactants and products, and of the pressure drop through the bed. Mass transfer resistance of the gas film is less than $3 \%$ of the overall reaction resistance under the restricted conditions of the experiments. Longitudinal diffusion may contribute a higher percent.

These results are compared with the rate of exchange between hydrogen and deuterium measured by Holm and Blue. The effect of space velocity of the reacting gases on the rate of the exchange is more remarkable than that observed above.

\footnotetext{
* Faculty of Engineering, Nagoga University.
} 